\title{
PELAKSANAAN SUPERVISI IMUNISASI CAMPAK DI PUSKESMAS WILAYAH SURABAYA UTARA
}

\author{
MEASLES IMMUNIZATION SUPERVISON IN PUBLIC HEALTH CENTER OF NORTH SURABAYA
}

Dian Febrina Anggraini, Ratna Dwi Wulandari

Fakultas Kesehatan Masyarakat, Universitas Airlangga, Surabaya

E-mail: febrina_fix@yahoo.com

\begin{abstract}
Measles is one of endemic diseases in East Java especially in north Surabaya, the home of specific ethnic which resist of immunization. Surabaya District Health Office targeted their Measles immunization is above $90 \%$, but unfortunately this target are never been reached. The purpose of this study was to analyze the management process of immunization program, especially the supervision. The guidance of supervision is regulated in Health Minister Regulation number 42, on 2013. Supervision is involved performance standard setting, monitoring and corrective action. This is a quantitative study with descriptive and cross sectional design. The sampling was calculated by using simple random sampling. The interviews through open and close question were conducted to 38 Managers of Immunization program in Public Health Centre. The result showed that the implementation of supervision has implemented by guidance the supervision of immunization programme. The study showed that only $2.63 \%$ or just one of Public Health Centre has already supervised by District Health Office and $5.26 \%$ or two Public Health Centres has supervised three times and suit with guidance implementation of general supervision. From this study, it is important for District Health Office to add new person as Supervisor and Public Health Centres and ensure that its supervision follow the supervision guidance.
\end{abstract}

Keywords: Measles immunization, North Surabaya, supervision

\section{PENDAHULUAN}

Keberhasilan pembangunan kesehatan tidak terlepas dari peranan pelaksana program kesehatan. Pelaksana program bertindak sebagai tenaga yang melaksanakan program. Salah satu program pembangunan kesehatan yaitu imunisasi. Program imunisasi bertujuan agar dapat mengurangi tingginya Kejadian Luar Biasa (KLB) seperti Difteri, Campak, Polio, Hepatitis B, dan Pertusis. Berdasarkan data Direktorat Penyehatan Lingkungan dan Pengendalian Penyakit menunjukkan bahwa jumlah kasus Campak merupakan kasus yang masih KLB. Jumlah kasus tertinggi tepatnya di kota Surabaya, yaitu 955 (Profil Kesehatan Kota Surabaya, 2013) dengan cakupan imunisasi Campak di beberapa Puskesmas belum mencapai target sebesar $90 \%$

Mobilitas tinggi merupakan salah satu faktor yang mempengaruhi derajat kesehatan kota
Surabaya. Kota Surabaya memiliki 62 Puskesmas yang terbagi ke dalam 5 daerah, yaitu Surabaya Selatan, Surabaya Utara, Surabaya Timur, Surabaya Barat, dan Surabaya Tengah (Dinas Kesehatan Kota Surabaya, 2013). Selain itu, keberhasilan program pemberian imunisasi tidak terlepas dari input yang dibutuhkan, pelaksanaan, output dan impact yang terjadi.

Berdasarkan data dari Dinas Kesehatan Kota Surabaya pada tahun 2011 sampai dengan 2012, cakupan imunisasi Campak masih belum memenuhi target, yaitu 72,85 (target 2011adalah 90\%), 84,37 (target 2012 adalah 90\%), dan 93,62\% (target 2013 adalah 90\%). Walaupun target di tahun 2013 sudah terpenuhi yaitu 93,62\%, tetapi masih terdapat beberapa Puskesmas Kota Surabaya masih belum terpenuhi target imunisasinya. Belum tercapainya program imunisasi Campak di beberapa Puskesmas Kota Surabaya mengindikasikan bahwa 
terdapat kendala dalam pelaksanaan program imunisasi Campak. Pelaksanaan program imunisasi terdiri dari perencanaan kegiatan, pelaksanaan kegiatan dan evaluasi dan kontrol atau supervisi kegiatan. Penelitian ini bertujuan untuk mengetahui pelaksanaan supervisi program imunisasi Campak. Hasil penelitian diharapkan dapat membantu Puskesmas di kota Surabaya dalam mengetahui kinerja Pihak Dinas Kesehatan Kota Surabaya dan Pengelola program imunisasi dalam supervisi program imunisasi.

\section{PUSTAKA}

\section{Imunisasi Campak}

Campak merupakan penyakit infeksi virus akut yang menular dengan ditandai demam, batuk, konjungtivis, dan ruam kulit (Behrman, 2008). Penularan penyakit Campak terjadi melalui airbone dan jarang terjadi dengan kontak benda yang terkontaminasi sekresi hidung dan tenggorokan. Masa inkubasi bekisar 8-13 hari atau rata-rata 10 hari (Behrman, 2008). Salah satu upaya pencegahan penyakit Campak adalah dengan program Imunisasi. Imunisasi adalah cara untuk menimbulkan atau meningkatkan kekebalan seseorang secara aktif terhadap penyakit, sehingga jika terpapar dengan penyakit tidak akan sakit atau sakit ringan (Permenkes nomer 42 tahun 2013). Upaya imunisasi berkembang sebagai carauntuk pencegahan penularan terhadap penyakit yang dapat dicegah dengan imunisasi (PD3I). Kegiatan imunisasi terdiri dari imunisasi rutin, imunisasi anak sekolah, imunisasi ibu hamil, dan imunisasi tambahan (Direktorat Pengendalian dan Penyehatan Lingkungan, 2012).

Sasaran imunisasi Campak adalah bayi dan anak-anak. Imunisasi pada bayi diberikan kepada bayi yang berumur kurang dari satu tahun dengan satu dosis, sedangkan imunisasi Campak pada anak diberikan pada Siswa kelas 2 dan 3 SD sebagai upaya perlindungan jangka panjang terhadap penyakit (Akib, 2008). Berdasarkan Permenkes nomer 42 tahun 2013 tentang pedoman penyelenggaraan imunisasi, mekanisme penyelenggaraan imunisasi terdiri dari penyusunan perencanaan, pelaksanaan kegiatan imunisasi, dan evaluasi pelaksanaan imunisasi dalam bentuk supervisi dan bimbingan teknis.

Penyusunan perencanaan terdiri dari penentuan jumlah sasaran, perencanaan target cakupan, rencana kebutuhan vaksin, kebutuhan peralatan cold chain. Pelaksanaan imunisasi terdiri dari persiapan petugas imunisasi, persiapan masyarakat, pemberian pelayanan imunisasi, dan koordinasi. Evaluasi penyelenggaraan imunisasi melalui supervisi dan bimbingan teknis (Permenkes nomer 42 tahun 2013).

\section{Supervisi}

Supervisi adalah kegiatan yang terencana dari seorang pimpinan melalui aktifitas bimbingan, pengarahan, observasi, motivasi, dan evaluasi pelaksanaan kegiatan sehari-hari (Cole, 2001). Dalam manajemen, supervisi sama halnya dengan controlling. Kegiatan supervisi dalam pelaksanaan kegiatan terdiri dari penetapan standar kinerja, pemantauan kinerja, dan pengambilan tindakan korektif. 
Penetapan standar kinerja adalah proses menetapkan satuan pengukuran untuk penilaian kinerja. Standar adalah inti yang ditetapkan dengan melihat pada perencanaan program, dimana merupakan pedoman Supervisor yang bisa diukur dalam melihat implementasi dari perencanaan (Certo, 2002).

Pemantauan kinerja adalah kegiatan memantau pelaksanaan kegiatan melalui lisan, tertulis, pengujian, dan observasi. Dalam pemantauan kinerja, supervisor juga membandingkan setiap tahap dalam pelaksanaan suatu kegiatan dengan standar yang telah ditetapkan sebelumnya apakah pelaksanaan program atau kegiatan telah dilakukan sesuai dengan standar yang telah ada sebelumnya atau ditetapkan (Terry, 2010).Kemudian proses terakhir dari tahap supervisi adalah pengambilan tindakan korektif, yaitu merupakan upaya Supervisor dalam menginteversi hasil program saat pelaksanaan yang dilakukan setelah pengukuran terhadap kinerja (Cole, 2001). Menurut Omran (2001), pengambilan tindakan korektif terdapat tiga kelompok berdasarkan waktu intervensi, yaitu pre control, concurrent control, dan feedback control. Pre control adalah intervensi dalam pengambilan tindakan korektif yang dilakukan sebelum suatu kegiatan dilakukan. Concurrent control adalah intervensi dalam pengambilan tindakan korektif yang dilakukan saat kegiatan sedang berlangsung. Feedback control adalah intervensi dalam pengambilan tindakan korektif yang dilakukan setelah suatu kegiatan dilaksanakan.

Pengambilan tindakan korektif dalam kegiatan supervisi imunisasi Campak meliputi kegiatan diskusi dan analisis supervisi bersama dengan pemegang program imunisasi serta tindak lanjut terhadap hasil supervisi imunisasi Campak.

\section{METODE}

Penelitian ini merupakan penelitian kuantitatif dengan jenis penelitian deskriptif dan rancang bangun cross sectional (Sarwono, 2006). Populasi pada penelitian ini adalah seluruh Puskesmas di Kota Surabaya sejumlah 62 Puskesmas. Besar sampel penelitian ini spesifik di5 Puskesmas wilayah Surabaya Utara yang dipilih berdasarkan metode simple random sampling. Pengambilan data menggunakan kuesioner dengan pertanyaan terbuka dan tertutup kepada pemegang program imunisasi Campak di 5 Puskesmas wilayah Surabaya Utara. Penelitian ini dilakukan selama bulan Juni-Juli 2015.Data primer yang dikumpulkan melalui wawancara ditujukan untuk mengetahui kegiatan supervisi program imunisasi Campak sesuai dengan langkah yang ditetapkan ketika pelaksanaan supervisi atau tidak. Data yang telah diperoleh kemudian dilakukan pembandingan dengan standar supervisi imunisasi sesuai dengan Permenkes nomer 42 tahun 2013

\section{HASIL DAN PEMBAHASAN}

\section{Analisis Kegiatan Supervisi Imunisasi Campak}

Supervisi adalahkegiatan yang terencana dari seorang manajer melalui aktifitas bimbingan, pengarahan, observasi, motivasi, dan evaluasi pada stafnya dalam melaksanakan kegiatan atau tugas sehari-hari (Cole, 2001). Pelaksanaan kegiatan supervisi terdiri dari penetapan standar kinerja, 
pemantauan kinerja, dan pengambilan tindakan korektif (Omran, 2001).

Penetapan standar kinerja untuk supervisi imunisasi terdiri dari standar pengelolaan Pemantauan Wilayah Setempat (PWS), analisis dan tindak lanjut PWS, target capaian imunisasi, pedoman pencatatan dan pelaporan hasil program, logistik dan cold chain, peralatan imunisasi, pelayanan imunisasi, tenaga pelaksana di tingkat Puskesmas, penghitungan persen (\%) cakupan imunisasi, dan kerjasama lintas sektor dan program.

Berdasarkan hasil penelitian, didapatkan bahwa Puskesmas di wilayah Surabaya Utaraterdapat dokumen mengenai standar penetapan kinerja supervisi imunisasi Campak. sesuai dengan Permenkes no. 42 tahun 2013, yaitu standar pengelolaan Pemantauan Wilayah Setempat (PWS), analisis dan tindak lanjut PWS, melalui buku pedoman PWS KIA, target capaian imunisasi, pedoman pencatatan dan pelaporan hasil program, logistik dan cold chain, peralatan imunisasi, pelayanan imunisasi, tenaga pelaksana di tingkat Puskesmas, penghitungan persen (\%) cakupan imunisasi, dan kerjasama lintas sektor dan program.

Dalam pelaksanaan supervisi Imunisas Campak di Puskesmas, supervisi dilaksanakan dengan memberikan form tertulis berupa checklist supervisi dan pemantauan terhadap laporan hasil kegiatan imunisasi (George R. Terry, 2010). Pemantauan kinerja program imunisasi Campak dilakukan oleh Supervisor baik dari Dinas Kesehatan kota maupun Puskesmas. Kegiatan pemantauan kinerja untuk imunisasi Campak dilaksanakan sesuai dengan panduan checklist imunisasi Campak, yaitu pendataan jumlah sasaran Campak, penghitungan jumlah desa atau kelurahan rawan Campak, penghitungan jumlah peralatan imunisasi, vaksin, dan cold chain, pendataan kecukupan vaksin, pendataan jenis dan jumlah alat suntik yang digunakan,pendataan kebutuhan tenaga penyuntik, serta pencatatan dan pelaporan hasil imunisasi Campak.

Checklist tersebut sesuai dengan ketentuan dari Permenkes nomer 42 tahun 2013 tentang pedoman penyelenggaraan imunisasi. Kegiatan supervisi imunisasi Campak di Puskesmas kota Surabaya utara tidak hanya memantau proses kerja berlangsung, Namun dalam pelaksanaannya pemantauan kinerja adalah membandingkan dan menilai apakah kinerja yang dilakukan telah sesuai dengan standar yang ditetapkan sebelumnya atau tidak (Omran, 2001)

Menuruthasil wawancaradengan pengelola program imunisasi, mengenai pendataan jumlah sasaran Campak di wilayah Surabaya utara baik dari supervisor Dinas Kesehatan Kota Surabaya maupun Puskesmas telah dilakukan. pendataan jumlah sasaran Campak. Pendataan dilakukan dengan melihat laporan dan pencatatan hasil program imunisasi Campak mengenai ada tidaknya sasaran yang terkena Campak. Selain itu, Mengenai penghitungan jumlah desa atau kelurahan rawan Campak, Supervisor dari Dinas Kesehatan kota dan Puskesmas telah melakukan pendataan mengenai penghitungan jumlah desa atau kelurahan rawan Campak dengan melihat pada pelaporan dan pencatatan hasil program imunisasi Campak yang 
dilakukan setiap bulan, apakah terdapat sasaran yang terkena Campak atau tidak.

Pendataan jumlah sasaran Campak adalah pendataan atau pencatatan mengenai sasaran yang harus diimunisasi Campak (Permenkes nomor 42 tahun 2013). Imunisasi Campak menurut waktunya dibagi atas imunisasi rutin dan Bulan Imunisasi Anak sekolah (BIAS) pada anak. imunisasi rutin yaitu imunisasi yang dilaksanakan kepada bayi usia kurang dari satu tahun dengan Campak 1 dosis. Bulan Imunisasi Anak Sekolah adalah pemberian imunisasi yang dilaksanakan pada bulan agustus untuk imunisasi Campak kepada anak sekolah kelas 1. Tujuan BIAS adalah untuk memberikan perlindungan jangka panjang.

Terkait dengan penghitungan jumlah peralatan imunisasi, vaksin, dan cold chain dalam pelaksanaan supervisi imunisasi Campak di Puskesmas wilayah Surabaya Utaratelah dilakukan penghitungan terhadap jumlah peralatan imunisasi, vaksin, dan cold chain. Penghitungan yang dilakukan oleh Supervisor baik dari Dinas Kesehatan Kota atau dari Puskesmas berpedoman pada cara menghitung jumlah peralatan imunisasi, vaksin, dan cold chain menurut Permenkes nomer 42 tahun 2013 tentang pedoman penyelenggaraan imunisasi, yaitu dengan menggunakan indeks pemakaian peralatan imunisasi yang telah dipakai.

Untuk pendataan mengenai peralatan lengkap seperti penyimpanan vaksin, peralatan imunisasi dan cold chainsudah dilakukan oleh Supervisor baik dari Dinas Kesehatan Kota dan Puskesmas.Selanjutnya adalah mengenai pendataan kecukupan vaksin di Puskesmas wilayah
Surabaya Utara dalam pelaksanaan supervisi imunisasi Campak, menyatakan bahwa supervisor baik dari Dinas Kesehatan Kota maupun Puskesmas, telah melakukan pendataan tentang kecukupan vaksin. Berdasarkan Permenkes nomer 42 tahun 2013, pendataan kecukupan vaksin pada dasarnya adalah menghitung kebutuhan jumlah dosis vaksin berasal dari unit pelayanan imunisasi atau Puskesmas. Cara menghitung kecukupan akan kebutuhan vaksin berdasarkan beberapa hal seperti jumlah sasaran imunisasi Campak, target cakupan imunisasi Campak, dan indeks pemakaian vaksin tahun sebelumnya.Penghitungan kebutuhan vaksin untuk unit layanan imunisasi swasta disesuaikan dengan jumlah cakupanabsolut tahun lalu. Jika terjadi kesenjangan yang cukup tinggi terkait dengan penggunaan vaksin tidak sesuai dengan kebutuhan, maka dapat disebabkan karena banyak sasaran yang datang dari luar wilayah atau sasaran yang pergi ke wilayah lain (Permenkes Nomer 42 tahun 2013).

Dalam menghindari penumpukan vaksin, jumlah kebutuhan vaksin dikurangi dengan sisa vaksin tahun lalu. Kebutuhan dalam satuan jumlah dosis dikonversi dalam satuan ampul atau vial dan volume vaksin. Hasil penelitian 5 Puskesmas wilayah Surabaya utara saat pemantauan terhadap pendataan kecukupan vaksin imunisasi Campak, supervisor baik Dinas Kesehatan Kota maupun Puskesmas melihat laporan hasil imunisasi Campak dan catatan mengenai kebutuhan dan penggunaan vaksin.

Mengenai pendataan jenis dan jumlah alat suntik yang digunakan, responden menyatakan 
bahwa Supervisor dari Dinas Kesehatan Kota Surabaya telah melakukan pendataan mengenai jenis dan jumlah alat suntik yang digunakan. Jenis alat suntik yang digunakan adalah Auto Disable Syringe (ADS). Selain itu, berdasarkan hasil wawancara dengan pemegang program imunisasi mengatakan bahwa alat suntik yang digunakan oleh semua Puskesmas harus menggunakan alat suntik jenis Auto Disable Syringe tersebut, karena dianjurkan oleh Dinas Kesehatan Kota Surabaya.

Berdasarkan hasil penelitian kepada petugas pengelola program imunisasi Puskesmas wilayah Surabaya Utara diperoleh bahwa beberapa Puskesmas tersebut dari keseluruhan Puskesmas kota Surabaya, telah dilakukan supervisi imunisasi Campak yang sesuai dengan checklist. Sesuai dengan cara pemantauan kinerja saat melakukan supervisi, yaitu dilakukan melalui pencatatan (Terry, 2010). Secara Namun, terkait frekuensi pelaksanaan supervisi yang dilakukan oleh Supervisor dari Dinas kesehatan kota terdapat perbedaan di setiap
Puskesmas. Hal ini dikarenakan jumlah Puskesmas yang ada di Kota Surabaya sebanyak 62 Puskesmas, sedangkan jumlah tenaga pelaksana supervisi hanya dua orang (berdasarkan wawancara oleh petugas pemegang program imunisasi).

Selain dari Dinas Kesehatan Kota

Surabaya, pelaksanaan supervisi terhadap program imunisasi Campak juga dilakukan oleh petugas pemegang program imunisasi di Puskesmas sendiri.Berdasarkan wawancara terkait dengan frekuensi pelaksanaan supervisi oleh Dinas Kesehatan Kota yang sesuai dengan ketentuan Permenkes nomer 42 tahun 2013 tentang pedoman penyelenggaraan imunisasi terkait pelaksanaan supervisi mengenai standar pelaksanaan supervisi oleh Supervisor yaitu selama tiga kali dalam setahun.

Berikut ini adalah frekuensi pelaksanaan supervisi imunisasi di Puskesmas wilayah Surabaya Utara yang dilakukan baik oleh pihak Dinas kesehatan Kota maupun Puskesmas.

Tabel 1 Imunisasi Campak Di Puskesmas Wilayah Surabaya Utara Oleh Dinas Kesehatan Kota Surabaya dan Puskesmas

\begin{tabular}{lcr}
\hline \multirow{2}{*}{$\begin{array}{c}\text { Nama Puskesmas Wilayah } \\
\text { Surabaya Utara }\end{array}$} & $\begin{array}{c}\text { Frekuensi pelaksanaan supervisi imunisasi Campak dalam periode satu } \\
\text { tahun oleh Pelaksana Supervisi }\end{array}$ \\
\cline { 2 - 3 } & $\begin{array}{c}\text { Pelaksana oleh } \\
\text { (Dinas Kesehatan Kota) }\end{array}$ & $\begin{array}{c}\text { Pelaksana oleh } \\
\text { (Puskesmas) }\end{array}$ \\
\hline Pegirian & $2 \mathrm{kali}$ & $3 \mathrm{kali}$ \\
\hline Sidotopo wetan & $2 \mathrm{kali}$ & $3 \mathrm{kali}$ \\
\hline Wonokusumo & $2 \mathrm{kali}$ & $12 \mathrm{kali}$ \\
\hline Kenjeran & $3 \mathrm{kali}$ & $12 \mathrm{kali}$ \\
\hline Bulak banteng & $2 \mathrm{kali}$ & $12 \mathrm{kali}$ \\
\hline
\end{tabular}

Tabel 1 menunjukkan bahwa hanya satu Puskesmas wilayah Surabaya Utara yang frekuensi pelaksanaan supervisi imunisasi Campak sudah memenuhi standar frekuensi supervisi yang dilakukan oleh Dinas Kesehatan Kota, namun 4 dari 5 Puskesmas lainnya hanya disupervisi sebanyak dua kali dalam satu tahun, Begitu juga supervisi yang dilkukan oleh internal Puskesmas wilayah Surabaya Utara dilakukan dengan metode yang berbeda-beda.

Model atau cara supervisi yang dimaksud oleh tiga Puskesmas dengan jumlah frekuensi12 kali 
dalam setahun yaitu Supervisor dari Puskesmas hanya melihat laporan hasil kegiatan imunisasi Campak, tanpa melakukan supervisi sesuai dengan prosedur supervisi secara umum, seperti pengecekan peralatan, perlengkapan, dan pelayanan secara langsung.

Loenvinsohn et al (2000) dalam sebuah penelitian terkait dengan frekuensi supervisimenyatakanbahwa ada pengaruh frekuensi supervisi terhadap efektifitas kinerja dan suatu bentuk supervisi sistematis akan berpengaruh terhadap pelayanan secara bermakna. Frekuensi pelaksanaan supervisibaik yang dilakukan oleh Dinas Kesehatan kota Surabaya maupunpihak Puskesmas, frekuensi mempengaruhi efektifitas program imunisasi. Frekuensi pelaksanaan supervisi yang dilakukan oleh Puskesmas didasarkan dengan kebijakan yang dibuat oleh setiap Puskesmas. Hal inilah yang mempengaruhi pencapaian target cakupan di setiap Puskesmas dapat tercapai atau belum tercapai sesuai target imunisasi Campak.

Pelaksanaan pemantauan kinerja mengenai pendataan jenis dan jumlah alat suntik oleh Supervisor dari dinas Kesehatan dan Puskesmas adalah melalui data atau laporan pemakaian peralatan yang digunakan ke beberapa tempat wilayah kerja Puskesmas seperti Puskesmas pembantu (Pustu), Poskeskel, dan Bidan Praktek Swasta (BPS).

Tahap berikutnya dalam pelaksanaan kegiatan supervisi imunisasi Campak adalah pengambilan tindakan korektif. Pengambilan tindakan korektif adalah upaya Supervisor dalam mengintervensi hasil program saat pelaksanaan yang dilakukan setelah pengukuran terhadap kinerja. Tindakan korektif dapat berupa upaya perbaikan terhadap penyebab masalah dan menurunkan target kinerja jika setelah diambil tindakan korektif juga tidak berubah (Cole, 2001).Hasil penelitian tentang pengambilan tindakan korektif ditunjukkan bahwa telah dilakukan di Puskesmas wilayah Surabaya Utara dengan diskusi dan analisis bersama serta melakukan tindak lanjut terhadap hasil analisis pelaksanaan imunisasi Campak antar pemegang program dengan Supervisor baik dari pihak Dinas kesehatan Kota Surabaya maupun Puskesmas sendiri. Pengambilan tindakan korektif yang dilakukan oleh Supervisor adalah melakukan perbaikan terhadap hasilkegiatan imunisasi Campak yang menjadi penyebab masalah berupa adanya beberapa program seperti validasi data yang dilakukan setiap bulan, namun baru diterapkan rutin setiap bulan mulai tahun 2015, sedangkan sebelumnya hanya dilaksanakantiga bulan sekali oleh Dinas Kesehatan Kota. Hal ini dilakukan juga oleh pihak Puskesmas sebagai Supervisor di wilayah kerjanya melakukan model supervisi melalui laporan data hasil kegiatan imunisasi setiap bulan.

Kegiatan tindak lanjut menurut waktunya yang diberikan oleh Supervisor dari Dinas Kesehatan kota maupun Puskesmas,yaitu tindak lanjut yang dilakukan berupa pre control dan feedback control(Omran, 2001). Pre control yaitu dilakukan sebelum kegiatan supervisi berupa kebijakan mengenai penyelenggaraan imunisasi sesuai pedoman Permenkes nomer 42 tahun 2013. Dikatakan juga dilakukan dengan feedback control yaitu berupa pelaksanaan supervisi yang dilakukan 
dengan waktu tertentu yang ditentukan berdasarkan Permenkes nomer 42 tahun 2013 tentang pedoman penyelenggaraan imunisasi.

\section{SIMPULAN}

Supervisi imunisasi Campak di Puskesmas wilayah Surabaya utara telah memenuhi standar pelaksanaan supervisi imunisasi berdasarkan Permenkes nomer 42 tahun 2013 tentang pedoman penyelenggaraan imunisasi, namun ada bagian dari pelaksanaan supervisi yang belum memenuhi standar pelaksanaan supervisi.

Penetapan standar kinerja berdasarkan Permenkes nomer 42 tahun 2013 telah dilaksanakan berupa pedoman tertulis pada PWS KIA. Kemudian untuk pemantauan kinerja, telah dialkukan berdasarkan checklist yang berpedoman pada Permenkes nomer 42 tahun 2013, namun terkait frekuensi pelaksanaan supervisi dari Dinas Kesehatan kota hanya satu Puskesmas yang dilaksanakan selama tiga kali dalam setahun, sedangkan Supervisor Puskesmas melakukan cara supervisi yang berbeda di setiap Puskesmas. Hanya dua Puskesmas yang melakukan supervisi sesuai dengan standar supervisi.

Terkait pengambilan tindakan korektif, telah dilakukan analisis dan diskusi serta tindak lanjut oleh Supervisor baik dari Dinas Kesehatan kota maupun Puskesmas. Kemudian, bedasarkan waktu pengambilan tindakan korektif di Puskesmas Kota wilayah Surabaya Utara yang dilakukan adalah pre control (sebelum pelaksanaan imunisasi terdapat kebijakan dalam penyelenggaraan imunisasi) dan feedback control (tindakan analisis dan evaluasi terhadap hasil kegiatan imunisasi serta adanya validasi data yang dilakukan oleh Supervisor).

Perlu adanya penambahan tenaga untuk tim supervisi imunisasi dari Dinas Kesehatan Kota Surabaya, sehingga frekuensi supervisi imunisasi di Puskesmas dilaksanakan sesuai standar. Selanjutnya, bagi Puskesmas kota Surabaya diharapkan agar tetap menjalankan supervisi imunisasi yang sesuai dengan ketentuan supervisi untuk efektifitas kerja.

\section{DAFTAR PUSTAKA}

Akib (2008). Manajemen Sumber Daya Manusia. Diakses 12 Februari 2015, dari Web Site Scrib.com

Behrman (2008). Imunisasi Dasar Lengkap. Diakses 10 Agustus 2015, dari Web Site eprints.undip.ac.id

Certo (2001). Planning and Controlling. Diakses 10 Agustus 2015, dari Web Site pathways learning education. org

Cole (2001). Supervision. Jakarta: Erlangga

Dinas Kesehatan Kota Surabaya (2012). Profil Kesehatan Dinas Kesehatan Kota Surabaya tahun 2012. Surabaya

Dinas Kesehatan Kota Surabaya (2013). Profil Kesehatan Dinas Kesehatan Kota Surabaya tahun 2013. Surabaya

Direktorat Pengendalian Penyakit dan Lingkungan, 2012. Pedoman Pengendalian Penyakit dan Penyehatan Lingkungan. Direktorat Pengendalian Penyakit dan Lingkungan.

Kementerian Kesehatan Republik Indonesia, 2013. Peraturan Menteri Kesehatan Republik Indonesia Tentang Pedoman Penyelenggaraan Imunisasi Nomor 42 Tahun 2013. Kementrian Kesehatan Republik Indonesia.Jakarta.

Loevinsohn, BP, Guererro, ET, Gregorio, SP, Improving Primary HealthCare Trough Sistematic Supervition, A Controled Field Administration Education, vol10:2, 2000. Maman Ukas (2004). Manajemen: Konsep, Prinsip dan Aplikasi. Bandung: Penerbit Agnini.

Omran (2001). Planning and Controlling. Diakses 10 Agustus 2015, dari Web Site pathways learning education.org.

Terry (2010). Skripsi:Evaluasi Manajemen Pelaksanaan Imunisasi Di Puskesmas Kabupaten Pasuruan. Surabaya: Universitas Airlangga. 